\title{
Tabularia
}

TABULARIA Sources écrites des mondes normands médiévaux

Autour de Serlon de Bayeux : la poésie normande aux

$\mathrm{XI}^{\mathrm{e}}-\mathrm{XII}{ }^{\mathrm{e}}$ siècles | 2016

\section{Serlo of Bayeux and England}

Serlon et l'Angleterre

Serlone e l'Inghilterra

\section{Elisabeth Van Houts}

\section{(2) OpenEdition}

\section{Journals}

Electronic version

URL: http://journals.openedition.org/tabularia/2600

DOI: $10.4000 /$ tabularia. 2600

ISSN: 1630-7364

Publisher:

CRAHAM - Centre Michel de Boüard, Presses universitaires de Caen

Electronic reference

Elisabeth Van Houts, "Serlo of Bayeux and England », Tabularia [Online], Autour de Serlon de Bayeux la poésie normande aux X|e-X|le siècles, Online since 12 July 2016, connection on 19 April 2019. URL http://journals.openedition.org/tabularia/2600; DOI : 10.4000/tabularia.2600 


\title{
Serlo of Bayeux and England
}

\section{Serlon et l'Angleterre}

\section{Serlone e l'Inghilterra}

\author{
Elisabeth VAN HouTs \\ Emmanuel College, Cambridge CB2 3AP (UK) \\ emcv2@cam.ac.uk
}

\begin{abstract}
:
After a short introduction highlighting Serlo's ambiguous attitude to the English and its king in 1105-1106, I shall discuss three texts which link Serlo with England. First there is Serlo's poem Defensio pro filiis presbyterorum of which the oldest copy is preserved (incompletely) in a manuscript of Exeter Cathedral c. 1100 (Cambridge CCC ms 190, p. 361). The first 59 lines, in a haphazard order, have survived and concentrate mainly on the sacrament of baptism, the fact that sons cannot be held responsible for the sins of their fathers and the legislators' lack of attention for simony and homosexuality. Second, I will discuss Serlo's poem ad Murielem, the versificatrix nun of Wilton (d. before 1113) which was written after Baudri of Bourgueil's poem for her. Thirdly and briefly I will explore the implications of the suggestion, first raised by Edoardo D'Angelo, that the poem Septem maiores numeramus was written by Serlo for Queen Edith Matilda (d. 1118), perhaps as a contribution to one of her competitions organised for poets.
\end{abstract}

Keywords: Serlo of Bayeux, Latin poetry, sons of priests, Bayeux, Muriel of Wilton, Queen Edith Matilda

\section{Résumé:}

Après une brève introduction mettant en évidence l'attitude ambiguë de Serlon envers les Anglais et leur roi dans les années 1105-1106, je présenterai trois textes qui évoquent les liens de Serlon avec l'Angleterre. Il s'agit d'abord du poème de Serlon Defensio pro filiis Presbyterorum, dont la plus ancienne copie est conservée (partiellement) dans un manuscrit de la Cathédrale d'Exeter daté des environs de 1100 (Cambridge CCC ms 190, p. 361). Les 59 premiers vers, conservés dans un ordre aléatoire, portent principalement sur le sacrement du baptême et sur le fait que les fils ne peuvent être tenus pour responsables des péchés de leurs pères et sur le manque d'attention porté par les législateurs aux questions de simonie et d'homosexualité. Ensuite, j'analyserai le poème ad Murielem, sur la religieuse versificatrice de Wilton († avant 1113), poème que Serlon écrivit après que Baudri de Bourgueil eut écrit celui qu'il consacra à cette religieuse. Enfin, brièvement, j'étudierai les implications de la suggestion, d'abord émise par Edoardo D'Angelo, selon laquelle le poème Septem maiores numeramus fut écrit par Serlon pour la reine Edith Matilda († 1118), peut-être comme une contribution à l'un des concours de poésie qu'elle organisa.

Mots-clés: Serlon de Bayeux, poésie latine, fils de prêtres, Bayeux, Muriel de Wilton, reine Edith Matilda 
Riassunto ${ }^{1}$ :

Dopo una breve introduzione volta a mettere in evidenza l'atteggiamento ambiguo di Serlone verso gli Inglesi ed il loro re negli anni tra il 1105 e il 1106, presenterò tre testi che evocano i rapporti di Serlone con l'Inghilterra. Si tratta innanzitutto della Defensio pro filiis Presbyterorum, poesia di Serlone la cui copia più antica è conservata (parzialmente) in un manoscritto della Cattedrale di Exeter datato all'incirca al 1100 (Cambridge CCC ms 190, p. 361). I primi 59 versi, serbati in un ordine casuale, vertono principalmente sul sacramento del battesimo e sul fatto che i figli non possono essere considerati responsabili dei peccati dei loro padri e sulla mancata attenzione rivolta da parte dei legislatori alle questioni della simonia e dell'omosessualità. In seguito, analizzerò la poesia ad Murielem, sulla religiosa versificatrice di Wilton († prima del 1113), testo che Serlone compose dopo quello che Balderico di Bourgueil dedicò alla stessa monaca. Infine, studierò brevemente le implicazioni del suggerimento, proposto per la prima volta da Edoardo D'Angelo, secondo il quale la poesia Septem maiores numeramus fu scritta da Serlone per la regina Edith Matilda († 1118), forse come contributo per uno dei concorsi di poesia da lei organizzati.

Parole chiave: Serlone di Bayeux, poesia latina, figli dei preti, Bayeux, Muriel di Wilton, regina Edith Matilda

At this conference dedicated to Serlo of Bayeux I would like to concentrate on Serlo's ties with England. Given his Norman birth he was extraordinary proud of the great Norman achievements of the eleventh century. In his poem about the English attack on Bayeux in 1105, De capta Baiocensium civitate, he sharply contrasted the cowardness of the Bayeux knights with the bravery of their ancestors conquering southern Italy and England in 1066:

Dregs of the Normans! Shame of your fathers and ancestors! While you turn your backs in flight, the praise earned by the virtue of previous generations has been hurled downwards, as has the fame accumulated by the Normans over the previous years. That wild fury, which once burned us fiercely [90] and used to attack the clergy with proud words, now lies wounded, when the necessity of warfare requires it... [And finally], would you care to recall ancient wars? [Indeed] the English chariots were conquered and fell without even lifting their weapons. [110] The men who fathered you conquered the English, whilst you degenerate sons are ready for all shameful deeds. The Normans waged wars with far more courage in the land of Sicily; those same Normans gave proofs and confirmation of their virtue in Calabria, [115] and their honourable deeds are known to the Apulian people. Conquered Rome learned to suffer the arms of good warriors. The conquered city of Le Mans is accustomed to being subject to the Normans; you, degenerate Bayeux, now avoid the swords of Le Mans. A rough enemy is present: why does your virtue lie hidden and shut away? [120] You are useless defenders, you who should defend us, and you shut yourselves off like this, while you shamefully listen to our groans ${ }^{2}$.

1. Translation by Laura VAngone, Centre de Recherches Archéologiques et Historiques Anciennes et Médiévales, Normandie Univ, UNICAEN, CNRS, CRAHAM, 14000 Caen, France.

2. Serlo of Bayeux, 2013, p. 57-105, Appendix 3, lines 85-91 (p. 90-3), 110-121 (p. 92-3), faex Normannorum! patrum pudor et proauorum!/ dum uertis dorsum fugiens, est uersa deorsum/ laus 
In other words the past superiority of the Normans is put to shame by the deplorable failure of the present day Bayeux soldiers to defend their city. Led by the local castellan Gontier of Aunay they fell ultimately under the responsibility of Duke Robert Curthose who therefore is equally - if indirectly - criticised. Yet, for all Serlo's scathing remarks on his Norman contemporaries at Bayeux the poem can at the same time be read as praise for Henry I, the Norman conqueror of Bayeux, leader of English troops who put the Bayeux knights to shame. Serlo, it seems, had begun a charm offence to the king of the English, whom he explicitly thanked for allowing the canons to leave their buildings without being attacked by his troops: "but our fate was such that the king's kindness did not allow us to suffer the arms of his frenzied troops" 3 . Bishop Odo, Serlo's erstwhile patron had died seven years earlier, and Serlo was preparing the ground for new patronage. With Odo's death in 1097 all English lands bestowed on him personally, rather than on the cathedral, had returned into the king's hand ${ }^{4}$. This probably included the only land identified in Domesday Book as held-inchief by the canons at Eltisley in Cambridgeshire, worth a considerable $£ 13$, as well as the lands in Surrey they held as Bishop Odo's tenants in Surrey ${ }^{5}$. It is a reasonable assumption that the canons may have made an effort to recoup some of their possessions and that Serlo's comments expressing gratitude to King Henry I have to been viewed in the context of this campaign that, we now know, ultimately failed.

Apart from the evidence in De capta, we can identify three links between Serlo with England, all of which can be dated roughly to the first fifteen years of the twelfth century. First, the earliest trace of Serlo's poem Rex immortalis (or "On the defence of priests' sons") can be found around 1100 in a manuscript belonging to Exeter cathedral. Second, the poem written for Muriel, the nunpoetess of Wilton nunnery in Wiltshire, was addressed to her before she died, which happened well before 1113. And third, the anonymous poem composed for Queen Edith-Matilda which on metrical grounds has been attributed potentially to Serlo has to be dated before her death in 1118 .

antiquorum uirtute parata uirorum,/ famaque Normannis cumulata prioribus annis./ impetus ille furens, quondam nos acriter urens/ et clerum uerbis solitus lacerare superbis,/ nunc iacet obtusus, cum belli postulat usus... [denique] bella uelis antiqua reuoluere? telis/ [namque] cadens laxis, domitus fuit Anglicus axis./ [110] Anglos uicerunt patres qui uos genuerunt/ degeneres natos et ad omnia probra paratos./ in Siculis oris, animi longe melioris,/ proelia gesserunt Normanni; signa dederunt/ uirtutisque fidem Calabris in finibus idem,/ [115] quorum res gestas gens Appula nouit honestas./ Roma subacta pati didicit gregis arma probati./ subdita Normannis urbs esse solet Cenomannis;/ tu Cenomannenses uitas, ut degener, enses./ hostis adest hirtus: quid clausa latet tua uirtus?/ [120] es defensor hebes, qui nos defendere debes,/ et sic te claudis, querulos dum turpiter audis.

3. Ibid., p. 96-97, lines 185-186: ...non permissit furialis/ arma subire gregis nos indulgentia regis.

4. BATES, 1975, p. 1-20 at p. 10 estimates the bishop's English landed wealth as totalling £3050.

5. For Eltisley, see Domesday Book, 1783, vol. I, [henceforth DB] fol. 196r and Domesday Book, 2002, p. 534; for the lands at Mitcham, "Whitford" and Ashtead in Surrey, see Domesday Book, 1783, vol. I, fol. $31 \mathrm{~V}$ and Domesday Book, 2002, p. 75-76. No traces have been found for canons' lands in England after 1086 (MAтTHEW, 1962, 72). I am grateful to David Bates for discussing the problem of the canons' English lands with me. 
Let me begin with the early English evidence for Serlo's poem Rex immortalis (On the defence of priests' sons) ${ }^{6}$. It has survived in four manuscripts: the Exeter cathedral manuscript, now Cambridge Corpus Christi College 190, p. 361, which contains only the first 59 out of 140 lines in an idiosyncratic order $^{7}$. Rome Vat. Reg. 598 (olim 1382), fol. 8v is a twelfth-century manuscript, while the two other manuscripts are from the thirteenth century, Oxford, Bodl. Lib. Laud Lat. 86 (olim 654) fols. 120-1 and Oxford, Bodl. Lib. Digby 65, fols. 8v-9. In the latter manuscript the poem is attributed to Serlo Parisiacensis. A fifth testimony to the early use of the poem can be found in the work of Theobald of Étampes (d. c. 1125), who was educated at Caen and then moved as teacher to Oxford ${ }^{8}$. He quoted a few lines of Serlo's poem in his letter to Roscelin of Compiègne (d. 1125), a defender of the new papal directives on clerical marriage and non-ordination of priests' sons ${ }^{9}$.

Rex immortalis was written in direct response to the council of Clermont in 1095 which had ruled against the ordination of priests' sons as secular priests themselves; they could only remain priests if they became monks or regular canons ${ }^{10}$. In the poem Serlo set out his main arguments: first baptism cleanses original sin and this sacrament makes all people equal regardless of who their parents are ${ }^{11}$ :

Everyone should carry the weight of their own sins and should not be damned for the sins of their fathers ${ }^{12}$.

In other words, priests' sons cannot be punished for sins committed by their fathers. Serlo also intimated that the power of baptism overrides that of all other sacraments (i.e., taking the Eucharist, or priestly ordination). He attacked men engaged in sex secretly, i.e. not within marriage, and not for the purpose of procreation, and pointed out that the Reformers are hypocrites because they do not implement any rules against homosexual activity:

6. Serlo of Bayeux, 1897, 579-583; The Anglo-Latin Satirical Poets, 1872, II, p. 208-12, Walther, $1969, \mathrm{n}^{\circ} 16733$.

7. The manuscript can be accessed in its entirety on the website "Parker Library on the Web".

8. Foreville, 1952, p. 81-100; Foreville, 1957, p. 1-51.

9. Patrologia Latina, $1844-1963$, vol. 163 , col. 767C-770D and Theobaldi Stampensis, 1897, p. 603-607. For Roscelin, see Mews, 2002. See below Appendix 1 for a comparison between Theobald's letter and Serlo's poem.

10. The Council of Clermont, c. 23, The Councils of Urban II 1, 1972, p. 79: Ne filiis presbiterorum, diaconorum, vel subdiaconorum ad ordines vel ad alios honores ecclesiasticos promoveantur, nisi monachus vel regularis canonicus fuerit.

11. Barstow, 1982, p. 134-138; Melve, 2010, p. 688-706 and Frauenknecht, 1997, p. 129-130. The importance of the sacrament of baptism is also present in the works of the Norman Anonymous and Theobald of Étampes.

12. Serlo of Bayeux, 1897, p. 580, lines 14-15, Quisque sui portet peccati pondus oportet/ Nec sit dampnatus patris pro crimine natu. 
Now men who live shameful obscene lives of sodomites/ and who perform these crimes in secret, rant at us in opprobrium/ and despise those illegitimately born even though they have good morals/ the law permits bad morals and oppresses the good ones... why should the legislators deprive by rule of law the illegitimately born when they lead good lives ${ }^{13}$ ?

Serlo's fury was directed in particular against those who commit homosexuality which brings the human race to extinction:

Why do you [legislators] avoid pressing a serious fine on the sodomites, their kind of sickness, which might cause a grievous end to the human race, ought by right to be rooted out first ${ }^{14}$.

These sentiments on baptism overriding other sacraments, and homosexuality being worse than being an illegitimate child of a married priest are strikingly similar to those expressed in the poem nos uxorati sumus, a poem also written in response to the Clermont regulations and since 1990 also attributed to Serlo ${ }^{15}$. However, this poem is far more explicit a defence of priestly marriage than a defence of the ordination of priests' sons. In his poem on the Fall of Bayeux written ten years later as a canon Serlo picked up fleetingly on some of these themes, though his tone had softened somewhat. He dared the Bayeux knights to become canons, to leave their wives, beds and wealth behind them:

Or join our flock and henceforth [125] observe the canonical rule, having become soldiers of the cloister. In this way the flock of our canons will grow well. So tonsured and weighed down by black cloth, go to solemnly recite the psalms, as is fitting; put on harmonious voices as you chant the hours. [130] Rejoice in having left behind that life which was so often praised, and which was declared blessed by your judgement... You ordained as holy men by an irrevocable vow, will take our place and leave behind your brides, marriage beds, chambers and their fitting adornments, purses full of silver, gems and gold [140 $]^{16}$.

13. Ibid., p. 581, lines 34-37, 44: Nunc homines vite turpis, mocha, sodomite/ Et qui furta patrant, in nos obprobria latrant/Vel bene moratos, et despiciunt male natos: lex permit ista bonos et sublevat ad mala pronos... Ergo censure talis quo regula iure/ sorte sua privat male natum, si bene vivat?

14. Ibid., lines 49-51: Quid pena vitas urgere gravi sodomitas?/ Hex species morbi, qua mors gravis imminent orbi, so bene res isset, prius extirpanda fuisset.

15. Serlo of Bayeux, 199o, p. 188-192 at p. 189-190; Serlo of BAyeux, 1980, p. 398-399.

16. Serlo of Bayeux, 2013, p. 94-95, lines 124-140: uel nostra formam sumens gregis, admodo normam/ canonicam seua, claustralis facta caterua. [125] sic bene nostrorum grex crescet canonicorum./ ergo coronati pannisque nigris onerati/ ad psalmos rite promendos, ut dicet, ite;/ cantas horas uoces aptate canoras./ uitam laudatam totiens, uestroque beatam/ [130] iudicio dictam, uobis gaudete relictam./ ...uos sancti facti stabilis sub foedere pacti/ nuptas atque toros, camera, cultusque decoros, / argento plenas gemmis auroque crumenas, nobis linquetis, postquam loca nostra tenetis./ [139] 
This passage seems an unambiguous reference to the poet's situation as an unmarried secular canon of Bayeux cathedral ${ }^{17}$. It accords with the admittedly dramatic picture of his collapsed house affected by the fire forcing him to eat burnt bread alone amongst the ruins ${ }^{18}$. No mention of a woman in this context. If Serlo never had a wife or concubine, he was something of an exception in Bayeux around the turn of the century ${ }^{19}$. On the other hand, if Serlo is the author of the poem nos uxorati sumus then, clearly, at some stage he had been a married canon-priest.

Let me return, however, to the links with England. As I have said before, the oldest (incomplete) copy of Serlo's Rex immortalis (or “On the defence of priests' sons") comes from England. It was added to a blank sheet in an eleventh-century manuscript of Exeter cathedral, now Cambridge Corpus Christi College MS 190 (p. 361), containing liturgical, homiletic and penitential texts. The addition has been dated variously to the late eleventh (Patrick Wormald) or the very early twelfth century (Böhmer and the present cataloguer of the Parker Library) or a range combining these two dates (Joyce Hill) ${ }^{20}$. The order of the first 59 lines (out of 140) is different from the continental copies, which - according to Böhmer and Dümmler in the $M G H$ edition - represents the original order ${ }^{21}$. The unique line order is probably due to the fact that the Exeter exemplar had the poem written in a confusing layout - as sometime poems were written on scraps of parchment or in the margin of existing texts ${ }^{22}$. The English provenance is significant evidence for insular interest in the issue of clerical celibacy and ordination of priests' sons. In particular, it reveals interest at Exeter in the views against papal legislation to implement priests' celibacy ${ }^{23}$. Clerical marriage had been forbidden at the council of Westminster in 1076, the first occasion after the Norman conquest when William the Conqueror and Lanfranc began to implement reform policies

17. There is no evidence for the imposition of the rule of St Augustine under Odo or Odo's successor Turold de Brémoy (1098-1106); for Turold, about whom very little is known, see BouEt and Dosdat, 1995, p. 19-37 at p. 25. For the chapter at Bayeux, see Spear, 2006, p. 31-88 and SPEAR, 2014, p. 151-194 at 160-165.

18. Serlo of BAyeuX, 2013, p. 96-99, lines 190-195: cumque cremaretur mea res, et iam pateretur [190] omnem defectum quod serierat mihi tectum,/ spe captus uana, frumenti tollere grana de cinerum massa coepi mediocriter assa./ nam flammis raptam faciendis panibus aptam/annonam rebar, sed prorsus decipiebar [195].

19. BROOKE, 1956, p. 1-21.

20. WORMALD, 1999, p. 220-224 for the Cambridge manuscript, a miscellany of Old English legal and homilytic texts in two parts from Exeter cathedral. The first part, dated to the early eleventh century, can be identified as the "Canon in Latin and Confessional in English", one of the books acquired by Bishop Leofric (1046-1072) for Exeter cathedral (p. 220). The second part, dated to the middle of the eleventh century (Wormald, p. 222), contains on p. 361 as a late eleventh-century addition (p. 222 figure 4.5) the earliest known (incomplete) copy of Serlo's poem, with a late medieval title Invectivum in damnantes coniugia sacerdotum. Wormald did not identify Serlo's poem. For the identification of this manuscript as one of Bishop Leofric's books, see now HiLL, 2011, p. 145-161 at 158-159.

21. The poem is incomplete presenting the lines ordered as 1-17, 21, 22, 18-20, 23-8, 41-4, 34-7, 29-33, 45-59, 38-40; the rest is missing, see Serlo of BAyeuX, 1897, p. 579.

22. VAN Houts, 2014, p. 1-22 at p. 5-6.

23. For married clergy in Exeter later in the twelfth century, see BARLOW, 1995, p. 95-109. 
current in Normandy. These prohibitions were repeated at the Westminster council (September 1102), London (May 1108), Westminster (September 1125), Westminster (May 1127) and London (October 1129) ${ }^{24}$. Given the need for repetition, implementation was virtually non existent ${ }^{25}$. In fact, despite the numerous efforts of Henry I, or at least his archbishops, England lagged behind Normandy and the rest of Europe with regard the implementation of papal policy. The fact that the poem is pro-priests' sons and ordination of priests' sons and their status as providers of pastoral care indicates resistance at Exeter cathedral to implementation of prohibition to ordain priests' sons and probably also clerical celibacy around 1100 .

At the time that Serlo's poem Rex immortalis was copied at Exeter the bishop was Osbern fitzOsbern (d. 1103), brother of William fitzOsbern (d. 1071), both cousins of William the Conqueror. In c. 1100 Bishop Osbern of Exeter was an aged man three years away from his death. He had been in England for most of his adult life, because c. 1050 as a young secular clerk he had come to England to serve at the court of King Edward the Confessor (1041/2-1066) ${ }^{26}$. Although he owed his promotion to the bishopric in 1072 to the Norman king he was probably at least as English as he was Norman in outlook given his longstanding career in England. In fact, Cambridge, Corpus Christi College MS 190, containing Serlo's Rex immortalis, has - as we have heard - been identified as one of the books bequeathed by Bishop Osbern to Exeter cathedral upon his death in 1103 . Serlo's poem was not the only work imported from Normandy to Exeter around the same time. The other text is the so-called Exceptiones Normannorum, the abbreviated copy of the earliest version of William of Jumièges' Gesta Normannorum Ducum redaction $C^{27}$. This Exeter abbreviation of the GND can be dated quite precisely to the last years of Bishop Osbern's life, 1101-110 ${ }^{28}$. It is important for its historical testimony. Local English information about the fitzOsbern family and Exeter's castellan William of Vauville is inserted as well as some English annalistic detail, turning the text into the first hybrid Anglo-Norman history. On the issue of clerical celibacy, priests' sons and their ordination, we may speculate that Osbern probably represented more the views of his cousin Bishop Odo of Bayeux than those of William the Conqueror and Lanfranc. What is interesting is that in this south western corner of England Serlo's poem against the Council of Clermont was copied beautifully on a blank page in a manuscript that started out as a copy of Wulfstan of York's early eleventh-century writings on proper behaviour for the clergy. The Corpus manuscript accumulated lots

24. Councils and Synods, 1981, vol. II, $\mathrm{n}^{\circ} 113, \mathrm{p} .665-688$ at p. 675-676 clauses 5-8 and letters of Anselm, p. 684-7 (1102 Westminster), $\mathrm{n}^{\circ} 116$, p. 694-703, clauses 1-2, p. 700-701 (1108 London); $\mathrm{n}^{\circ}{ }^{130}$, p. 733-741, clause 13, p. 740 (1125 Westminster); n 743-49, clause 5, p. 747-748 (1127 Westminster); $\mathrm{n}^{\circ} 134$, p. $750-754$ (London 1129). For a discussion, see BretT, 1975, p. 77, 79-82.

25. Thibodeaux, 2013, p. 46-76; Thibodeaux, 2015, p. 46-57; Fenton, 2013, p. 64-77.

26. BAXTER and LEWIS, forthcoming in autumn 2016.

27. The Gesta Normannorum Ducum of William of Jumièges, 1992-1995, vol. II, p. 290-304.

28. Ibid., p. 290. Note, however, that manuscript London, BL Cotton Vespasian A xviii fol. 157r-162v dates from the first half of the twelfth century, see BAXTER and LEwIS, forthcoming in autumn 2016. 
of other eleventh-century pastoral guidance texts, including Eremfrid of Sion's penitential ordo and the list of tariffs for penance issued by the Norman bishops to the fighters at Hastings who were deemed to have committed sinful acts during the conquest in $1067^{29}$. This collection of texts constitutes important evidence for early English thinking about the effects of the Norman conquest and papal reform policies in England. I will come back to this issue in a moment but now I want to turn to the second of Serlo's links with England.

As we have noted, Serlo composed a poem to Muriel ${ }^{30}$. She was a nun at the royal nunnery of Wilton in Wiltshire ${ }^{31}$. The poem, incorrectly attributed to Serlo Parisiacensis, is known from one manuscript only, London BL Vitellius A xii, fols 109r-110r, a famous collection of Latin poetry from the eleventh and twelfth centuries $^{32}$. The poem cannot be dated other than before 1113, the year when the canons of Laon came to Wilton where they visited the nun's grave ${ }^{33}$ ! In that same year the mortuary role of Abbess Matilda of Holy Trinity Caen, who had just died, was presented to the nuns of Wilton. They added one of the role's shortest prose entries, which we might accept as indirect evidence that Wilton had lost its celebrated versificatrix, poetess, the label Muriel was given on her tombstone $^{34}$. She was celebrated in England and on the continent where apart from Canon Serlo of Bayeux, the bishop-poets Baudri of Bourgueil (1046-1130) and Hildebert of Lavardin, bishop of Le Mans and archbishop of Tours (1056-1133), addressed poems to her ${ }^{35}$. Baudri knew her personally as he specifically mentions their conversations, presumably during one of his trips to England, probably before $1102^{36}$. He addressed her as relatively young, whereas in Serlo's poem too, as Boutémy observed, she is depicted either as novice or as someone on the brink of promising her vow because the poet warned her not to give in to pressure from family and friends to remain in the world ${ }^{37}$. Since Serlo also referred to Baudri himself as Muriel's Maro vester and a vates comparable to Virgil, it seems likely that Serlo's poem postdates Baudri's. But Serlo is the more informative about Muriel's background. According to him, she was of noble origins and came

29. Councils and Synods, 1972, II, n ${ }^{\circ} 88$, p. 581-584 and The Norman Conquest, 1984, $\mathrm{n}^{\circ} 187$, p. 156-157.

30. Serlo of BAyeuX, 1872, II, p. 233-240. WAlther, 1969, nº 4912; Signori, 1995, p. 69-79.

31. FOOT, 2000, p. 221-231.

32. Воutémy, 1937 , p. $278-313$. The poet Serlo of Paris (or Wilton) lived in the second half of the twelfth century, see Rigg, 1992, p. 70-72 and Serlo of Wilton, 1965, p. 1-2.

33. TATLOCK, 1933, p. 317-321; RigG, 1992, p. 66: authenticity of Serlo's poem "seems certain"; Stevenson, 2005, vol. II, p. 86-107 at 95.

34. Rouleaux des morts $d u I X^{e}$ au $X V^{e}$ siècle, 1861, p. 189, $\mathrm{n}^{\circ}{ }_{15}$, Titulus sanctae Mariae et sanctae Edgithe Wiltoniensis ecclesiae. anima ejus et anime omnium fidelium defunctorum requiescant in pace. Amen Orate pro nobis. See also, Letouzey-Réty, 2011, vol. I, p. 155 [without mentioning Muriel]. La Trinité had lands just north of Wilton at Tilshead, though she dates that gift to "not later than 1131", see Charters and customals of the Abbey of Holy Trinity Caen, 1982, p. 28-32, 46-48.

35. BAudri De Bourgueil, 1998-2002, vol. II, p. 46-47, n 137 and commentary vol. II, p. 218-219; Hildebertus Cenomannensis episcopus, 2001, $\mathrm{n}^{\circ}$ 26, p. 17-18.

36. Ibid., $\mathrm{n}^{\mathrm{o}} 137$, line 2 quam modo magnificat gratia colloquii, II, p. 219. For the date, see Ibid., II, p. 220.

37. Boutémy, 1935, p. 241-251 at p. 243-244 and p. 247 (identification with Muriel married to Eude au Chapel). 
from overseas (as viewed from Wilton), presumably Normandy, where the name was common. Boutémy's suggestion that she was Bishop Odo's sister Muriel, mentioned by Wace, ought to be rejected, as this Muriel was married to Eudes au Chapel ${ }^{38}$. What is surprising about Serlo's poem for Muriel, written it seems at her own request, is that it is a thoroughly pro-monastic one. He praised her as a virgin, denouncing in unmistakenly misogynistic fashion the married state as inferior and less preferable for women. If so, and if the Nos uxorati sumus poem was indeed Serlo's work, he seems to either apply double standards for men and women, or he changed his mind during his long career. As we have seen in his poem De capta on the capture of Bayeux (1105-1106), in which he invited the coward knights of Bayeux to become canons and give up their wives and marriage beds, Canon Serlo had already begun to express an anti-marriage position. Therefore, all we can say is that Muriel was almost certainly a Norman woman on the threshold of becoming a nun in England, whose Latin was precocious enough for her to appreciate sophisticated Latin verse. Her epithet versificatrix, recorded by the canons of Laon cathedral, indicated that she herself was an accomplished (Latin) poet. None of her work has, however, survived. She may have learned her Latin at Wilton, where the educational standards were exceptionally high for a nunnery. The hagiographer Goscelin of Saint-Bertin (d. after 1108) wrote his Latin Liber confortatorius (Book of Consolation) for the nun Eve (of Lotharingian-Danish descent), who later ran away and settled as a hermit in Angers (France), while the Scottish princess Edith, later Queen Matilda (d. 1118) was well educated as we shall hear in a moment ${ }^{39}$. Alternatively, Muriel was not only schooled in Wilton but may already have had an education in Normandy ${ }^{40}$. If she was given as a lettered Norman oblate to Wilton we may see a reverse parallel with Orderic Vitalis who as an educated English boy was given to a Norman monastery to increase the penitential value of the child gift by sending him overseas ${ }^{41}$.

There is no unambiguous evidence that Serlo and Muriel's fellow poet Baudri of Bourgueil knew each other. But it is worth noting that Baudri had been present at the council of Clermont in 1095, attended by Odo of Bayeux (d. 1097), two other Norman bishops and, almost certainly, Serlo as well ${ }^{42}$. If this is the case the two men may have met there. Perhaps Baudri brought a copy of the poem

38. I agree with Tilliette: Baudri de Bourgueil, Poèmes, 1998-2002, vol. II, p. 219 note 1, that Peter Dronke's suggestion (without citing evidence) that she came from Angers ought to be rejected. For Bishop Odo's siblings, though not Muriel, see The Domesday Monachorum of Christ Church Canterbury, 1944, p. 34-35; she appears with her husband as a witness for gifts to the abbey of Lessay as uxoris Heudonis Murielis 14 July 1080 or later: Regesta Regum Anglo-Normannorum Ducum, 1998, $\mathrm{n}^{\circ} 175$, p. 577-584 at p. 583; WACE, 2002, III, lines 6003-6006, p. 228-229: E Yon manda al Chapel/ qui a feme aveit Muriel/ seror le duc de par sa mere/ e Herluin aveit sa pere.

39. Goscelin of Saint Bertin, 1955, p. 1-117; Goscelin of Saint Bertin, 2004; for literacy in Old English and Latin at Wilton, see Hollis, 2004, p. 307-338.

40. For male education at Caen, see Foreville, 1952; for female education at Caen, see LetouzeyRÉTY, 2011. There is scope for more study of education in eleventh and twelfth-century Normandy.

41. Chibnall, 1984, p. 10-11.

42. Baudri de Bourgueil, 1998-2002, vol. I, p. 11. 
Rex immortalis (on the defence of priests' sons) with him to England, where - as we have seen - he met Muriel in person, presumably at Wilton, and where he also visited Worcester ${ }^{43}$.

The third link between Serlo and England is a most tentative one, based on a recently suggested attribution to Serlo of a well known poem to Queen Edith-Matilda, wife of King Henry I. The poem in question is Septem maiores numeramus, which according to Edoardo D'Angelo was written in a similar verse style to that used by Serlo ${ }^{44}$. The poet identified Edith-Matilda as a daughter of a king and queen (Malcolm and Margaret of Scotland) and a wife of a king (Henry I), an unsurprising theme referred to in the seven other poems known to have been written for the queen by, amongst others, Marbod of Rennes (10961123), Hildebert of le Mans and other anonymous poet(s). Septem maiores numeramus is thematically original - as far as its contents is concerned - for the poet's praise for Edith-Matilda as the eight major star in the sky also stressed her influence and persuasion with her husband, King Henry $\mathrm{I}^{45}$.

Caesar, [Henry I], listened to her [Edith-Matilda], abolished unjust laws and for the public good accepted good ones. May the woman fortunate with her husband, and the man happy with his wife, both live with their longlasting fame.

Unfortunately, we do not know which laws are referred to here, or what the occasion was that gave rise to Edith-Matilda's request. It therefore remains a mystery whether the poet referred to secular laws or ecclesiastical laws. It is worth pondering if this might be a reference to the king's leniency (of sorts) by allowing the clergy to remain married in lieu in return for a fine. Sometime between 1105 and 1108 he took advantage of Archbishop Anselm's exile to use the married priests as a source of income but it seems that he had to abandon this policy, only to resurrect it much later in $1129^{46}$. According to Eadmer, on the earlier occasion two hundred priests approached the king barefoot in London to implore him to change his mind. When he refused, the priests turned to the queen: "She, it was said, was so touched with sympathy that she dissolved into tears, but was too afraid to intervene" ${ }^{47}$. Eadmer's testimony is important evidence for Queen Edith-Matilda's sympathy for the plight of the married priests (and their wives)

43. According to Tilliette, Baudri visited England several times and wrote four poems about the church at Worcester with its organ (Ibid., p. 9, vol. II, p. 147-149, n 218-222).

44. WALTHER, 1969, $\mathrm{n}^{\circ} 17532$; BoUTÉMY, 1937, p. 304-305, $\mathrm{n}^{\circ}$ 8, Septem maiores numeramus in aethere stellas. For the tentative attribution, see D'ANGELO, 2014, p. 307-326 at 315-316.

45. ВоuтÉmY, 1937, p. 304-5, nº 8, lines 25-26, Exaudiuit eam Caesar, depressit iniquas/ leges, suscepit publica cura bonas, / Fortunata uiro mulier, uir coniuge felix,/ Longaeuus fama uiuat, uterque sua.

46. Eadmeri Historia Novorum in Anglia, 1884, p. 175-176 (Letter from Archbishop Anselm to Henry I asking him to stop the practice in 1108); Henry, Archdeacon of Huntingdon, 1996, VII, c., p. 482-485 (on 1129). For a commentary, see Brooke, 1956, p. 19 note 62; BRETT, 1975, p. 79.

47. Eadmeri Historia Novorum in Anglia, 1884, p. 173: Illa, ut fertur, pietate mota in lacrimas solvitur, sed timore constricta ab interventione arcetur. For a commentary, see BARRow, 2015, p. 138 and $\mathrm{n}^{\circ} 128$. 
even though on this occasion Eadmer did not credit her with having had any influence on her husband's actions. It may still be significant in this context that the resurrection of the imposition of fines on the married priests did not happen until a decade after Edith-Matilda's death. If my interpretation of the poem can be accepted it is evidence that Latin poetry may be viewed as a barometer measuring reactions to current affairs in the Anglo-Norman realm on both sides of the Channel.

If we can accept Septem maiores numeramus as Serlo's poem, it would constitute important information for Serlo having had contact with EdithMatilda, either personally or indirectly. Only one visit of Edith-Matilda is known for Normandy, just after the battle of Tinchebray, when she and her son William Adelin joined Henry for a triumphant tour ${ }^{48}$. Otherwise, she spent her time in England, acting as regent for Henry during his many absences in the duchy. Although, of course, Serlo could have written the poem for her on the occasion of her visit to Normandy - in which case it seems strange that he does not once refer to her as countess or duchess - it seems far more likely that it was written for an English occasion. Perhaps Serlo submitted Septem maiores numeramus for one of the competitions Edith-Matilda is known to have organised for poets, a custom which itself is evidence for both her love of poetry, presumably in Latin but conceivably also in English and perhaps Anglo-Norman. According to William of Malmesbury, she:

took especial pleasure in hearing divine service and for that reason took more thought than was wholly wise for the clerks with sweet voices; she had a winning word for each, and would give them rich gifts and promised richer. The news of her liberality consequently spread through the world, and hither flocked in troops and scholars who had a name for singing or for turning verses; and happy he thought himself the man who could please his lady's ear with a new song. Nor were they the only recipients of her bounty; it went to all sorts of men, especially to foreigners, who might accept her presents, and then advertise her fame in other countries ${ }^{49}$.

Serlo would certainly fit the bill as a foreign clerk sending in poems in search of patronage. His poems for Bishop Odo and the anonymous noble benefactor for whom he wrote on the fall of Bayeux show him to be a consummate artist rewarding patrons with an immortal reputation ${ }^{50}$.

48. Adelard of Bath, 1998, p. 52 (cum eorum regineque rogatu citharam tangeres); HUNEYCUTT, 2003, p. 86, 142 and Cochrane, 1994, p. 5 (visit dated to 1105).

49. William of Malmesbury, 1999, vol. I, p. 756-757; VAN Houts, 1989, p. 39-62.

50. Serlo of BAYeUX, 2013, p. 104-105, lines 330-334: me putet ingratum cui promitto famulatum,/ munus sponte datum nisi reddam multimplicatum./ reddam thesaurum qui gemmas uincit et aurum, / qui famam seruat laudesque merentis aceruat, / dans infinitam post mortis tempora uitam. (May the man to whom I promise servitude think me ungrateful, if I do not repay many times over a gift that he gave unasked. I will give him in return a treasure better than gems and gold, something which preserves a deserving person's reputation and increases their praise, giving him immortal life after death). 
Let me move to a conclusion. I hope to have shown that Serlo had contacts in England, definitely with the nun Muriel at Wilton, more tentatively with Bishop Osbern of Exeter's clergy at Exeter, and perhaps with the court of Queen EdithMatilda. As I have pointed out in my other work on Serlo it remains very difficult to understand what his precise take on clerical marriage was. In his Norman work we can discern some slippage from being unambiguously in favour of married clergy (in Nos uxorati sumus) to gradual resignation that canons need to abstain from women (Rex immortalis). The Muriel poem's strong anti-marriage message for women is seemingly at odds with Serlo's pro marriage stance earlier in his career. The links with England are unsurprising for a Norman clergyman in the post-conquest Anglo-Norman realm. He represented the second generation of clergy marvelling at the Norman conquests in Southern Italy and England, though resisting the reform tendencies of Lanfranc and Anselm. He remains, ultimately, a thoroughly enigmatic poet if only because in the end he wrote to please his potential patrons and that meant expressing what he thought they would like to hear even if it meant compromising his own opinion ${ }^{51}$.

\section{Bibliographie}

\section{Sources}

Adelard of Bath, Conversations with his Nephew. On the Same and the Different, Questions on Natural Science, and On Birds, Charles BurnetT (ed. and tr.), Cambridge, Cambridge University Press, 1998.

Baudri de Bourgueil, Poèmes, Jean-Yves Tilliette (ed. and tr.), Paris, Belles Lettres, 1998-2002, 2 vol.

Charters and custumals of the Abbey of Holy Trinity Caen, Marjorie Chibnall (ed.), Oxford, Oxford University Press (Records of social and economic history, New series, 5), 1982.

Councils and Synods with other Documents relating to the English Church I: A.D. 8711204, Dorothy Whitelock, Martin Brett, Christopher N.L. Brooke (eds.), Oxford, Clarendon Press, 1981, 2 vol.

The Councils of Urban II 1: decreta Claromontana, Robert Somerville (ed.), Amsterdam, Hakkert (Annuarium Historiae Conciliorum, Suppl. 1), 1972.

Domesday Book A Complete Translation, Ann Williams and Geoffrey Haward MarTin (eds. and tr.), London, Penguin book (Penguin classics), 2003.

Domesday Book, seu liber censualis Willelmi primi regis Angliae inter archivos regni in Domo capitulari West monasterii asservatus, Jubente rege augustissimo Georgio tertio praelo mandatus, Abraham FARLEY (ed.), London, Nichols, 1783, 2 vol.

The Domesday Monachorum of Christ Church Canterbury, David C. Douglas (ed.), London, Royal Historical Society, 1944.

51. I am most grateful to David Bates, and for the comments and corrections received from the anonymous reader; any remaining errors are mine. 
Eadmeri Historia Novorum in Anglia, Martin Rule (ed.), London, Longman (Rerum Britannicarum Medii Aevi Scriptores, 81), 1884.

The Gesta Normannorum Ducum of William of Jumièges, Orderic Vitalis and Robert of Torigni, Elisabeth Maria Cornelia VAN Houts (ed. and tr.), Oxford, Clarendon Press (Oxford Medieval Texts), 1992-1995, 2 vol.

Goscelin of Saint Bertin, Liber confortatorius, in Charles Holwell Talbot (ed.), Analecta Monastica, III, Rome (Studia Anselmiana, 37), 1955, p. 1-117.

Goscelin of SAInt Bertin, The Book of Encouragement and Consolation, Monica OtTer (ed.), Cambridge, Derek Brewer (Library of Medieval Women), 2004.

Henry, Archdeacon of Huntingdon: Historia Anglorum, The History of the English People, Diana Greenway (ed.), Oxford, Clarendon Press (Oxford Medieval Texts, 53), 1996.

Hildebertus Cenomannensis episcopus, Carmina minora, Alexander Brian Scotт (ed.), Munich, K. G. Saur (Bibliotheca scriptorum Graecorum et Romanorum Teubneriana), 2001.

The Norman Conquest, Reginald Allen Brown (tr.), London, Arnold (Documents of Medieval History, 5), 1984.

Patrologia Latina, Paris, Migne, 1844-1963, 221 vol.

Regesta Regum Anglo-Normannorum. The Acta of William I (1066-1087), David BAtes (ed.), Oxford, Clarendon Press, 1998.

Rouleaux des morts du IX au XV siècle, Léopold DelisLe (ed.), Paris, Jules Renouard, 1861.

Serlo of Bayeux, De capta Baiocensium civitate, Moreed Arbabzadah (ed. and tr.), in Elisabeth Maria Cornelia VAN Houts, “The fate of priests' sons in Normandy with special reference to Serlo of Bayeux", Haskins Society Journal, 25, 2013, p. 57-106, Appendix 3, p. 86-91.

Serlo of Bayeux, Nos uxorati sumus, John Boswell (tr.), in Christianity, Social Tolerance and Homosexuality: Gay People in Western Europe from the Beginning of the Christian Era to the Fourteenth Century, Chicago, University of Chicago Press, 1980, p. 398-399.

Serlo of Bayeux, Nos uxorati sumus, Robert Lenzen (ed.), in "Sodomitenschelte. Eine Invektive des Serlo von Bayeux?" in Arbor amoena comis. 25 Jahre Mittellateinisches Seminar in Bonn 1965-199o, Ewald KöNSGEN (ed.), Stuttgart, Steiner, 1990, p. 188-192.

Serlo of BAyeux, Rex immortalis, Ernst Dümmler and Heinrich Böhmer (eds.) in MGH, Libelli de Lite, vol. 3, Hanover, Hahn, 1897, p. 579-583.

Serlo of BAyeux, Versus Serlonis Parisiacensis ad Muriel sanctimonialem. Inc. Dum nostrum poscis carmen, in The Anglo-Latin Satirical Poets and Epigrammatists of the Twelfth Century, Thomas Wright (ed.), London, Longman (Rerum Britannicarum Medii Aevi Scriptores, 59), 1872, p. 233-240.

Serlo of Wilton, Poèmes latins [de Serlo de Wilton], Jan ÖBerg (ed.), Stockholm, Almquist \& Wiksell (Acta Universitatis Stockholmiensis. Studia latina Stockholmiensia, 14), 1965.

Theobaldi Stampensis, Epistola ad Roscelinum, Heinrich BöHmer (ed.), MGH, Libelli de Lite, vol. 3, Hanover, Hahn, 1897, p. 603-607. 
WaCE, Robert, The Roman de Rou, III, lines 6003-6006, Glynn Sheridan Burgess (tr. and annot.), Anthony J. Holden (ed.), Elisabeth Maria Cornelia Van Houts (annot.), Saint Hélier, Société Jersiaise, 2002.

\section{Études}

BARLOw, Frank, "John of Salisbury and his brothers", Journal of Ecclesiastical History, 46, 1995, p. 95-109.

Barrow, Julia, The Clergy in the Medieval World. Secular Clerics, Their Families and Careers in North-Western Europe, c. 80o-c. 120o, Cambridge, Cambridge University Press, 2015.

Barstow, Anne Llewellyn, Married Priests and the Reforming Papacy: the EleventhCentury Debates, New York - Toronto, The Edwin Mellen Press (Texts and Studies in Religion, 12), 1982.

BATEs, David, “The character and career of Odo, bishop of Bayeux (1049/50-1097)", Speculum, 50, 1975, p. 1-20.

Bates, David and Bauduin, Pierre (eds.), 911-2011. Penser les mondes normands médiévaux, Caen, Presses universitaires de Caen (Symposia), forthcoming in autumn 2016.

BAXTER, Stephen and Lewis, Christopher P., "Comment identifier les propriétaires fonciers du Domesday Book en Angleterre et en Normandie? Le cas d'Osbern fitzOsbern", in 911-2011. Penser les mondes normands médiévaux, David BAtes and Pierre Bauduin (eds.), Caen, Presses universitaires de Caen (Symposia), forthcoming in autumn 2016.

Bouet, Pierre and Dosdat, Monique, "Les évêques normands de 985 à 1150", in Les évêques normands du XI siècle, Actes du colloque de Cerisy-la-Salle, 30 septembre3 octobre 1993, Pierre Bouet and François Neveux (eds.), Caen, Presses universitaires de Caen, 1995, p. 19-37.

Boutémy, André, "Muriel. Note sur deux poèmes de Baudri de Bourgueil et de Serlon de Bayeux", Le Moyen Âge, 45, 1935, p. 241-251.

Boutémy, André, "Notice sur le recueil poétique du manuscrit Cotton Vitellius A XII du British Museum", Latomus 1, 1937, p. 278-313.

Brett, Martin, The English Church under Henry I, Oxford, Oxford University Press (Oxford historical monographs), 1975.

BROOKE, Christopher Nugent Lawrence, "Gregorian reform in action: clerical marriage in England, 1050-1200”, The Cambridge Historical Journal, 12, 1956, p. 1-21.

Chibnall, Marjorie, The World of Orderic Vitalis, Oxford, Clarendon Press, 1984.

Cochrane, Louise, Adelard of Bath. The First English Scientist, London, British Museum Press, 1994.

D’Angelo, Edoardo, "Modèles classiques de l'hexamètre historiographique normand”, in L'historiographie médiévale normande et ses sources antiques, $X^{e}$-XII ${ }^{e}$ siècle, Actes du colloque de Cerisy-la-Salle et du Scriptorial d'Avranches (6-11 octobre 2009), Pierre Bauduin and Marie-Agnès Lucas-Avenel (eds.), Caen, Presses universitaires de Caen, 2014, p. 307-326. 
Fenton, Kirsten A., "Writing masculinity and religious identity in Henry of Huntingdon", Religious Men and Masculine Identity in the Middle Ages, Patricia H. Cullum and Katherine J. Lewis (eds.), Woodbridge, The Boydell press, 2013, p. 64-76.

Fоот, Sarah Rosamund Irvine, Veiled Women, vol. II, Female Religious communities in England 871-1066, Aldershot, Ashgate, 2000.

Foreville, Raymonde, "L'École de Caen au XI siècle et les origines normandes de l'Université d'Oxford", in Études médiévales offertes à M. le Doyen Augustin Fliche de l'Institut par ses amis, ses anciens élèves, ses collègues et publiés par le soins de la Faculté des Lettres de Montpellier, Publications de la Faculté de Lettres de l'Université de Montpellier, Paris, Presses universitaires de France, 1952, p. 81-100.

Foreville, Raymonde and LeClercQ, Jean, "Un débat sur le sacerdoce des moines au XII ${ }^{e}$ siècle”, Analecta Monastica 14 (Studia Anselmania, 41), Rome, 1957, p. 1-51.

Frauenknecht, Erwin, Die Verteidigung der Priesterehe in der Reformzeit, Hannover, Hahn (MGH, Studien und Texte, 16), 1997.

Hill, Joyce, “Two Anglo-Saxon Bishops at Work. Wulfstan, Leofric and Cambridge, Corpus Christi College MS 19o", in Patterns of Episcopal Power. Bishops in Tenth and Eleventh-Century Western Europe, Ludger KöRNTGEN and Dominik WassENHOVEN (eds.), Berlin, De Gruyter (Prinz-Albert-Forschungen, 6), 2011, p. 145-161.

Hollis, Stephanie J., "Wilton as a centre of learning", in Writing the Wilton Women. Goscelin's Legend of Edith and Liber Confortatorius, Stephanie Hollis, Rebecca HAyward et al. (eds.), Turnhout, Brepols (Medieval Women: Texts and contexts, 9), 2004, p. 307-340.

Huneycutt, Lois. L., Matilda of Scotland: A Study in Medieval Queenship, Woodbridge, Boydell Press, 2003.

LETOUZEY-RÉTY, Catherine, Écrits et gestion du temporel dans une grande abbaye de fermmes anglo-normande: la Sainte-Trinité de Caen (XI'-XII ${ }^{e}$ siècles), thèse de doctorat d'histoire médiévale, université de Paris I Panthéon-Sorbonne, 2011, 2 vol. (dactyl.).

Matthew, Donald, The Norman Monasteries and their English Possessions, Oxford, Oxford University Press (Oxford historical series, second series), 1962.

Melve, Leidulf, "The public debate on clerical marriage in the late eleventh century", Journal of Ecclesiastical History, 61, 2010, p. 688-706.

Mews, Constant J., Reason and Belief in the Age of Roscelin and Abelard, Aldershot, Ashgate (collected studies series), 2002.

Religious Men and Masculine Identity in the Middle Ages, Patricia H. Cullum and Katherine J. Lewis (eds.), Woodbridge, The Boydell press, 2013, p. 46-76.

RIGG, Arthur George, A History of Anglo-Latin Literature 1066-1422, Cambridge, Cambridge University Press, 1992.

Signori, Gabriela, "Muriel und die Anderen... oder Gedichte als Freundschaftspfand", Meine in Gott geliebte Freundin. Freundschaftsdokumente aus klösterlichen und humanistischen Schreibstuben, Gabriela Signori (ed.), Bielefeld, Verlag für Regionalgeschichte (Religion in der Geschichte. Kirche, Kultur und Gesellschaft 4), $1995\left(2^{\text {nd }}\right.$ ed. 1998$)$, p. 67-77. 
Spear, David S., The Personnel of the Norman Cathedrals during the Ducal Period, 911-1204, London, University of London (Fasti Ecclesiae Anglicanae, 1066-1300), 2006, p. 31-88.

Spear, David S., "Additions and corrections to David S. Spear, The Personnel of the Norman Cathedrals during the Ducal Period, 911-1204", Tabularia "Études", 14, 2014, p. 151-194.

Stevenson, Jane, “Anglo-Latin Women Poets", in Latin Learning and English Lore, vol. II: Studies in Anglo-Saxon Literature for Michael Lapidge, Katherine O’Brien O'Keeffe and Andy Orchard (eds.), Toronto, University of Toronto Press (Toronto Old English series, 14), 2005.

Tatrock, John S. P., "Muriel: The Earliest English Poetess", Publications of the Modern Language Association of America, 48, $\mathrm{n}^{\circ}$ 2, 1933, p. 317-321.

Thibodeaux, Jennifer D., "The defence of clerical marriage: religious identity and masculinity in the writings of Anglo-Norman clerics", in Religious Men and Masculine Identity in the Middle Ages, Patricia H. Cullum and Katherine J. Lewis (eds.), Woodbridge, The Boydell Press, 2013, p. 46-63.

Thibodeaux, Jennifer D., The Manly Priest. Clerical Celibacy, Masculinity, and Reform in England and Normandy, 1066-130o, Philadelphia, University of Pennsylvania Press (The Middle Ages series), 2015.

VAN Houts, Elisabeth Maria Cornelia, "Latin poetry and the Anglo-Norman court 1066-1135: the Carmen de Hastingae Proelio", Journal of Medieval History, 15, 1989, p. 39-62.

Van Houts, Elisabeth Maria Cornelia, "The Planctus on the death of William Longsword (943) as a source for tenth-century culture in Normandy and Aquitaine", AngloNorman Studies, 36, 2014, p. 1-22.

WAlther, Hans, Initia Carminum ac versuum medii aevi posterioris latinorum. Ergänzungen und Berichten zur 1. Auflage von 1959, Göttingen, Vandenhoeck \& Ruprecht (Carmina Medii Aevi Posterioris Latina, I, 1), 1969.

William of Malmesbury, Gesta Regum Anglorum, The History of the English Kings, c. 418, vol. I, Roger Aubrey Baskerville Mynors, Rodney M. Thomson, Michael Winterbotтом (eds.), Oxford, Clarendon Press (Oxford Medieval Texts), 1999, 2 vol., p. 756-757.

Wormald, Patrick, The Making of English Law. King Alfred to the Twelfth Century, vol. 1, Legislation and its Limits, Oxford, Blackwell, 1999. 


\section{Appendix 1. Comparison between Theobald's borrowings from Serlo's Rex immortalis}

\begin{tabular}{|c|c|}
\hline Theobald to Roscelin PL163 c. 767-770 & $\begin{array}{l}\text { SERLO, Rex immortalis, BÖHMER (ed.) } \\
\text { MGH }\end{array}$ \\
\hline c. 769 , lines $35-46$, c. 770 , line 3 & $\begin{array}{l}\text { Libelli de Lite, vol. III, p. } 579-583 \text { at } \\
\text { p. } 580-581\end{array}$ \\
\hline $\begin{array}{l}\text { Quia nimirum quemlibet sacro fonte } \\
\text { renatum } \\
\text { vel plenaria divina mundat gratia vel } \\
\text { sacri }\end{array}$ & $\begin{array}{l}8 \text { Fonte sacro lotum vel mundat gratia } \\
\text { totum }\end{array}$ \\
\hline $\begin{array}{l}\text { mundatio lavacri non est sufficiens nec } \\
\text { plenaria; } \\
\text { quod contradicit fides catholica. Non } \\
\text { enim sunt }\end{array}$ & $\begin{array}{l}9 \text { vel non est sacri mundatio plena } \\
\text { lavacri. }\end{array}$ \\
\hline $\begin{array}{l}\text { exleges judicandi, quorum Deus ipse } \\
\text { Pater } \\
\text { et quos peperit Christi gratia omnium } \\
\text { regeneratorum }\end{array}$ & $\begin{array}{l}28 \text { Est Deus ipse pater peperit quos } \\
\text { gratia mater }\end{array}$ \\
\hline $\begin{array}{l}\text { piissima mater; nec debemus illis } \\
\text { delictum patris }\end{array}$ & $\begin{array}{l}29 \mathrm{Ne} \text { cures patris mihi delictum neque } \\
\text { matris }\end{array}$ \\
\hline $\begin{array}{l}\text { sive thorum matris improperare sed } \\
\text { potius morum } \\
\text { perfectionem diligenter attendere: } \\
\text { quoniam patris sive matris perpetratum } \\
\text { crimen } \\
\text { non potest filiis }\end{array}$ & $\begin{array}{l}30 \text { Improperare thorum sed forma } \\
\text { respice morum }\end{array}$ \\
\hline $\begin{array}{l}\text { paradisi claudere limen. Unde quidam } \\
\text { sapiens: }\end{array}$ & $\begin{array}{l}17 \text { Alterius crimen paradisi claudere } \\
\text { limen }\end{array}$ \\
\hline $\begin{array}{l}\text { Quid meruere pati quocunque thoro } \\
\text { generati? } \\
\ldots\end{array}$ & $\begin{array}{l}3 \text { Quid meruere pati quocunque toro } \\
\text { generati? }\end{array}$ \\
\hline $\begin{array}{l}\text { Six [Sic?] itaque illi prolatores novitatis } \\
\text { nova }\end{array}$ & 10 Hec qui tractatis prolatores novitatis \\
\hline praecepta dantes & $\begin{array}{l}11 \text { Dum nova jura datis lavacri jus } \\
\text { evacuatis }\end{array}$ \\
\hline
\end{tabular}

